\title{
New records of marine planktonic invertebrates from the Caribbean coast of Costa Rica
}

\author{
Allan Carrillo-Baltodano ${ }^{1,3}$, Álvaro V. Morales-Ramírez ${ }^{1,2}$, Jeffrey A. Sibaja-Cordero ${ }^{1,2}$ \\ \& Jorge Cortés ${ }^{1,2}$ \\ 1. Escuela de Biología Universidad de Costa Rica, 2060 San José, Costa Rica; acarrillobaltodano@clarku.edu \\ 2. Centro de Investigación en Ciencias del Mar y Limnología (CIMAR), Universidad de Costa Rica, San Pedro, \\ 11501-2060 San José, Costa Rica; alvaro.morales@ucr.ac.cr; jeffro@costarricense.cr; jorge.cortes@ucr.ac.cr \\ 3. Current address: Biology Department, Clark University, 950 Main Street, Worcester, MA 01610, USA
}

Received 05-X-2017. Corrected 24-X-2017. Accepted 03-I-2018.

\begin{abstract}
The coral reef at Cahuita National Park in the Caribbean coast of Costa Rica represents very diverse marine ecosystem. Most of this diversity knowledge has been the result of benthic surveys, while very little is known from pelagic studies. A zooplankton survey sampling was conducted monthly from September 2010 to August 2011, finding new records of marine invertebrates: 32 for the Caribbean coast of Costa Rica, seven for Costa Rican water and 16 for the Caribbean coast of Central America. These reports include the hoplitomella larva of the sponge Thoosa sp., larval stages of three lophophorates, seven families, five genera and six species of polychaetes, a juvenile of the lancet Branchiostoma (Phylum Chordata, Subphylum Cephalochordata) and four pelagic chordates. Analyzing the zooplankton of Cahuita, is an essential approach to studying not only the diversity, but also enhances the possibility of better understanding the ecological goods and services that the coral reef can provide. Rev. Biol. Trop. 66(Suppl. 1): S66-S82. Epub 2018 April 01.
\end{abstract}

Key words: Cahuita, coral reef, marine invertebrate larva, polychaetes, zooplankton.

Coral reefs are the most diverse marine ecosystems, with an estimate of as many as 9 million species worldwide (Plaisance, Caley, Brainard, \& Knowlton, 2011; Fisher et al., 2015). The Caribbean region is not the exception, with over 12000 species in all marine realms (Miloslavich et al., 2010). Most of the reported diversity lies on the benthic fauna, like so many marine habitats (Angel, 1993). But a significant portion is also on the pelagic realm, which harbors a vast diversity of fish and zooplankton (Suárez-Morales \& Rivera, 1998). Coral reef zooplankton includes holoplanktonic (e.g. microcrustaceans, appendicularians, chaetognats), meroplanktonic (e.g. marine invertebrate larvae and ichthyoplankton) or epibenthic forms (e.g. microcrustaceans) (Emery, 1968; Glynn, 1973). The species records for these components of zooplankton are being understood in combination with DNA barcoding and phylogeographic studies to better assessed the dynamics of the planktonic communities (Bucklin et al., 2010).

In the Caribbean coast of Costa Rica, most of the coral reef studies have focused on benthic fauna and reef fishes (Cortés \& Jiménez, 2003; Fonseca \& Gamboa, 2003). These studies had emphasized the fringing reef at Cahuita National Park as having relatively low diversity, due to siltation and anthropogenic impacts on the coral reef (Cortés \& Risk, 1985; Cortés, Jiménez, Fonseca, \& Alvarado, 2010). Morales-Ramírez \& Murillo (1996) suggested that this degradation also affects the meroplankton, presumably reducing the spawning events, feeding or swimming behavior of 
larvae. Meroplanktonic forms are of interest, because they could contribute to the benthic diversity, connectivity and dispersal of coral reef organisms (Heidelberg, Sebens, \& Purcell, 2004). Here, we present new records of marine invertebrates represented by meroplankic and holoplanktonic organisms, collected from the coral reef of Cahuita National Park, Caribbean coast of Costa Rica. We present these new records across a variety of invertebrate clades, to highlight the diversity of groups that have been underrepresented or unnoticed by performing benthic surveys.

\section{MATERIAL AND METHODS}

From September 2010 to August 2011, two 5 min horizontal tows were done at six stations in Cahuita's coral reef (either between 6:0010:00 or 12:00-17:00) (Fig. 1, Table 1). Once a month, two samples of zooplankton were collected using a WP net $0.47 \mathrm{~m}$ in diameter and a $200 \mu \mathrm{m}$ mesh, attached with a calibrated flow meter and a buoy to maintain the net at approximately $1 \mathrm{~m}$ depth. Samples were fixed with a $4 \% \mathrm{v} / \mathrm{v}$ formaldehyde in seawater, and transferred to $70 \%$ ethanol for preservation.

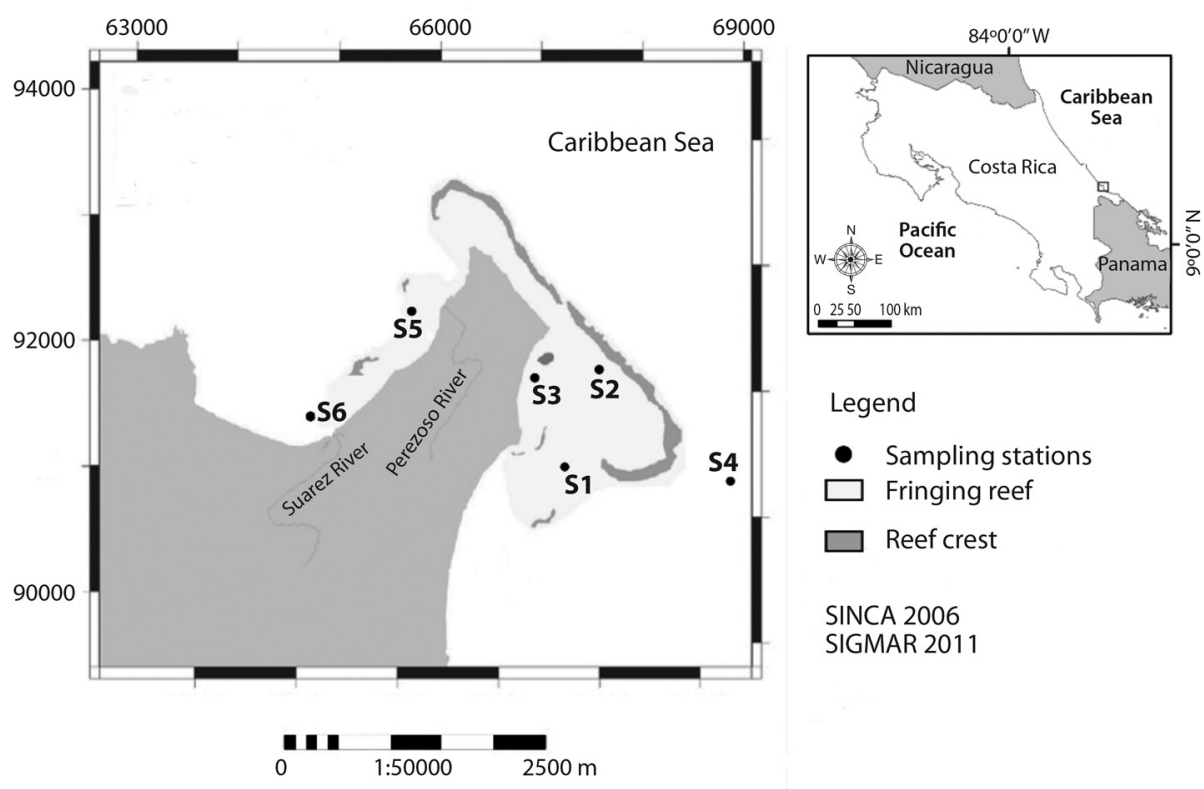

Fig. 1. Location of the stations sampled between September 2010 and August 2011 at Cahuita National Park, Limón, Costa Rica (modified from Fonseca, Salas, \& Cortés, 2006).

TABLE 1

Geographical coordinates of the stations sampled at Cahuita National Park, Limon, Costa Rica

\begin{tabular}{ccc} 
Station & Range of bottom depth $(\mathrm{m})$ & Coordinates \\
\hline 1 & $4-6$ & $9^{\circ} 44^{\prime} 09.85^{\prime \prime} \mathrm{N}-82^{\circ} 48^{\prime} 23.96 ” \mathrm{~W}$ \\
2 & $2-3.5$ & $9^{\circ} 44^{\prime} 31.25^{\prime \prime} \mathrm{N}-82^{\circ} 48^{\prime} 13.52^{\prime \prime} \mathrm{W}$ \\
3 & $1.5-2$ & $9^{\circ} 44^{\prime} 30.45^{\prime \prime} \mathrm{N}-82^{\circ} 48^{\prime} 30.88^{\prime \prime} \mathrm{W}$ \\
4 & $10-15$ & $9^{\circ} 44^{\prime} 03.30^{\prime \prime} \mathrm{N}-82^{\circ} 47^{\prime} 29.43^{\prime \prime} \mathrm{W}$ \\
5 & $5-7.5$ & $9^{\circ} 44^{\prime} 43.00^{\prime \prime} \mathrm{N}-82^{\circ} 49^{\prime} 18.69^{\prime \prime} \mathrm{W}$ \\
6 & $4-6$ & $9^{\circ} 44^{\prime} 16.30^{\prime \prime} \mathrm{N}-82^{\circ} 49^{\prime} 40.53 ” \mathrm{~W}$ \\
\hline
\end{tabular}


Subsamples of $2 \mathrm{ml}$ were sorted and quantified until reaching a minimum of 400 zooplankters. Specimens were separated by group; unknown meroplanktonic and holoplanktonic specimens were sorted from the sample for taxonomic analysis. Here we report the new records for the Caribbean coast of Costa Rica. Annelids were deposited in the Museo de Zoología, Universidad de Costa Rica (MZ-UCR).

\section{RESULTS}

We report in this study the occurrence of the larval forms of 13 invertebrate taxa, including an hoplitomella larvae of the boring sponge Thoosa, "lophophorates" larval stages: an actinotroch of phoronids, ciphonaute of bryozoans and lobate of brachiopods. We also report seven families (six as larval stages and the remaining as adults or epitokes), five genera and six species of polychaetes as new records for the Caribbean coast of Costa Rica. Of those polychaete families found, only adult stages of Amphinomidae, Sabellidae, Spionidae and Syllidae were reported previously for this location (Dean 2009, 2012, 2017) (Table 2). Unidentified larvae of echinoids and ophiurids, as well as unidentified larvae of mollusks

TABLE 2

New records of marine invertebrate fauna from the coral reef of Cahuita National Park. NR: new record; X: previously recorded; CR: Costa Rican waters; CarCR: Caribbean of Costa Rica; CarCA: Caribbean coast of Central America.

\begin{tabular}{|c|c|c|c|c|}
\hline \multirow[t]{2}{*}{ Taxa } & \multicolumn{3}{|c|}{ Record status } & \multirow[t]{2}{*}{ Life stage } \\
\hline & CarCR & $\mathrm{CR}$ & CarCA & \\
\hline \multicolumn{5}{|l|}{ Phylum Porifera } \\
\hline \multicolumn{5}{|l|}{ Class Demospongiae } \\
\hline Family Thoosidae & NR & $\mathrm{X}$ & $\mathrm{X}$ & \\
\hline Thoosa sp. & NR & $\mathrm{X}$ & $\mathrm{X}$ & Hoplitomella larva \\
\hline \multicolumn{5}{|l|}{ Phylum Brachiopoda } \\
\hline Class Lingulata & NR & $\mathrm{X}$ & NR & \\
\hline Family Lingulidae & NR & $\mathrm{X}$ & NR & \\
\hline ?Lingula sp. & NR & NR & NR & Larvae \\
\hline \multicolumn{5}{|l|}{ Phylum Bryozoa } \\
\hline Class Gymnolaemata & $\mathrm{X}$ & $\mathrm{X}$ & $\mathrm{X}$ & Cyphonautes larvae \\
\hline \multicolumn{5}{|l|}{ Phylum Phoronida } \\
\hline ?Phoronis sp. & NR & NR & $\mathrm{X}$ & Actinotroch larva \\
\hline \multicolumn{5}{|l|}{ Phylum Annelida } \\
\hline \multicolumn{5}{|l|}{ Class Polychaeta } \\
\hline Family Alciopidae & NR & $X$ & NR & \\
\hline Alciopina parasitica & NR & $\mathrm{X}$ & NR & Adult \\
\hline Family Amphinomidae & $\mathrm{X}$ & $\mathrm{X}$ & $\mathrm{X}$ & \\
\hline Hipponoe gaudichaudi & NR & NR & NR & Larva \\
\hline Family Magelonidae & NR & $\mathrm{X}$ & $\mathrm{X}$ & \\
\hline Magelona sp. & NR & $\mathrm{X}$ & $\mathrm{X}$ & Metatrochophore larvae \\
\hline Family Maldanidae & $\mathrm{X}$ & $\mathrm{X}$ & $\mathrm{X}$ & Larvae \\
\hline Family Paraonidae & NR & $\mathrm{X}$ & $\mathrm{X}$ & \\
\hline Aricidea (Acmira) simplex & NR & NR & $\mathrm{X}$ & Adult \\
\hline Family Pectinariidae & NR & $\mathrm{X}$ & NR & Larvae \\
\hline Family Phyllodocidae & NR & $\mathrm{X}$ & $\mathrm{X}$ & \\
\hline ?Sige sp. & NR & $\mathrm{X}$ & $\mathrm{X}$ & Metatrochophore larvae \\
\hline Family Sabellidae & $\mathrm{X}$ & $\mathrm{X}$ & $\mathrm{X}$ & \\
\hline Parasabella jamaicensis & $\mathrm{X}$ & $\mathrm{X}$ & $\mathrm{X}$ & Juvenile \\
\hline Family Spionidae & $\mathrm{X}$ & $\mathrm{X}$ & $\mathrm{X}$ & Metatrochophore larvae \\
\hline Family Syllidae & $\mathrm{X}$ & $\mathrm{X}$ & $\mathrm{X}$ & \\
\hline
\end{tabular}


TABLE 2 (Continued)

\begin{tabular}{|c|c|c|c|c|}
\hline Taxa & \multicolumn{3}{|c|}{ Record status } & Life stage \\
\hline Subfamily Autolytinae & NR & $\mathrm{X}$ & $X$ & Adult epitoke, male polybranchius \\
\hline Subfamily Eusyllinae & $\mathrm{X}$ & $\mathrm{X}$ & $\mathrm{X}$ & \\
\hline Odontosyllis sp. & $\mathrm{X}$ & $\mathrm{X}$ & $\mathrm{X}$ & Larva \\
\hline Subfamily Exogoninae & $\mathrm{X}$ & $\mathrm{X}$ & $\mathrm{X}$ & \\
\hline Exogone breviantennata & NR & $\mathrm{X}$ & NR & Adult \\
\hline Subfamily Syllinae & $\mathrm{X}$ & $\mathrm{X}$ & $\mathrm{X}$ & \\
\hline Syllis cf. armillaris & NR & NR & $\mathrm{X}$ & Adult \\
\hline Trypanosyllis parvidentata & NR & NR & $\mathrm{X}$ & Adult \\
\hline Family Terebellidae & NR & $\mathrm{X}$ & $\mathrm{X}$ & Larva \\
\hline Family Trichobranchidae & NR & $\mathrm{X}$ & $\mathrm{X}$ & Larva \\
\hline Phylum Chordata & & & & \\
\hline Subphylum Cephalochordata & NR & $\mathrm{X}$ & NR & \\
\hline Family Branchiostomidae & NR & $\mathrm{X}$ & NR & \\
\hline Branchiostoma sp. & NR & $\mathrm{X}$ & NR & Juvenile \\
\hline Subphylum Tunicata & & & & \\
\hline Class Larvacea & & & & \\
\hline Family Fritillaridae & NR & $\mathrm{X}$ & NR & \\
\hline Fritillaria formica & NR & $\mathrm{X}$ & NR & Adult \\
\hline Fritillaria haplostoma & NR & $\mathrm{X}$ & NR & Adult \\
\hline Family Oikopleuridae & NR & $\mathrm{X}$ & $\mathrm{X}$ & \\
\hline Oikropleura longicauda & NR & $\mathrm{X}$ & NR & Adult \\
\hline Class Thaliacea & & & & \\
\hline Family Doliolidae & NR & $\mathrm{X}$ & $\mathrm{X}$ & \\
\hline Doliolum nationalis & NR & NR & NR & Ozooids blastozooids \\
\hline
\end{tabular}

were found year-round. Finally, in addition to meroplanktonic forms, we found a juvenile of the lancet Branchiostoma, and new holoplanktonic records represented by four members of Tunicata: three appendicularians and one salp. Altogether, we present 32 new reports for the Caribbean coast of Costa Rica, seven for Costa Rican waters and 16 for the Caribbean coast of Central America. Spatiotemporally mean abundance in for these groups at Cahuita NP is reported in Table 3.

\section{SYSTEMATICS}

Phylum Porifera Grant, 1836

Class Demospongiae Sollas, 1885

Order Astrophorida Sollas, 1887

Familiy Thoosidae Cockerell, 1925

Thoosa Hancock, 1849

Thoosa sp.

Locality: Puerto Vargas, Outer crest (Station (St.) 4): Nov 2010; Perezoso River (St.5):
Dec 2010; Shallow patch (St.3): Dec 2010; Deep patch (St.2): Dec 2010, Jun 2011.

Remarks: Larval specimens have strongyles-like plates, characteristic of the hoplitomella larvae of the astrophoridean sponge Thoosa (Maldonado \& Berquist, 2002; Bautista-Guerrero, Carballo, \& Maldonado, 2010). These larva lack cilia and have the characteristic spicules discostrongyles, and radiating styles. Thoosa sponges are viviparous, and use the radiating styles to get free from the parental tissue to the water column, where the styles get a buoyancy function (BautistaGuerrero et al., 2010).

Thoosa species have been found boring the corals Montastraea annularis (Ellis \& Solander, 1786) and Montastraea cavernosa (Linnaeus, 1767) in Belize (Highsmith, Lueptow, \& Schonberg, 1983), as well as in Cuba (Miloslavich et al., 2010; Table S3). Cortés, Van der Hal, \& Van Soest (2009) reported an unidentified species of an adult Thoosa from Punta Morales on the Pacific coast of Costa Rica. 


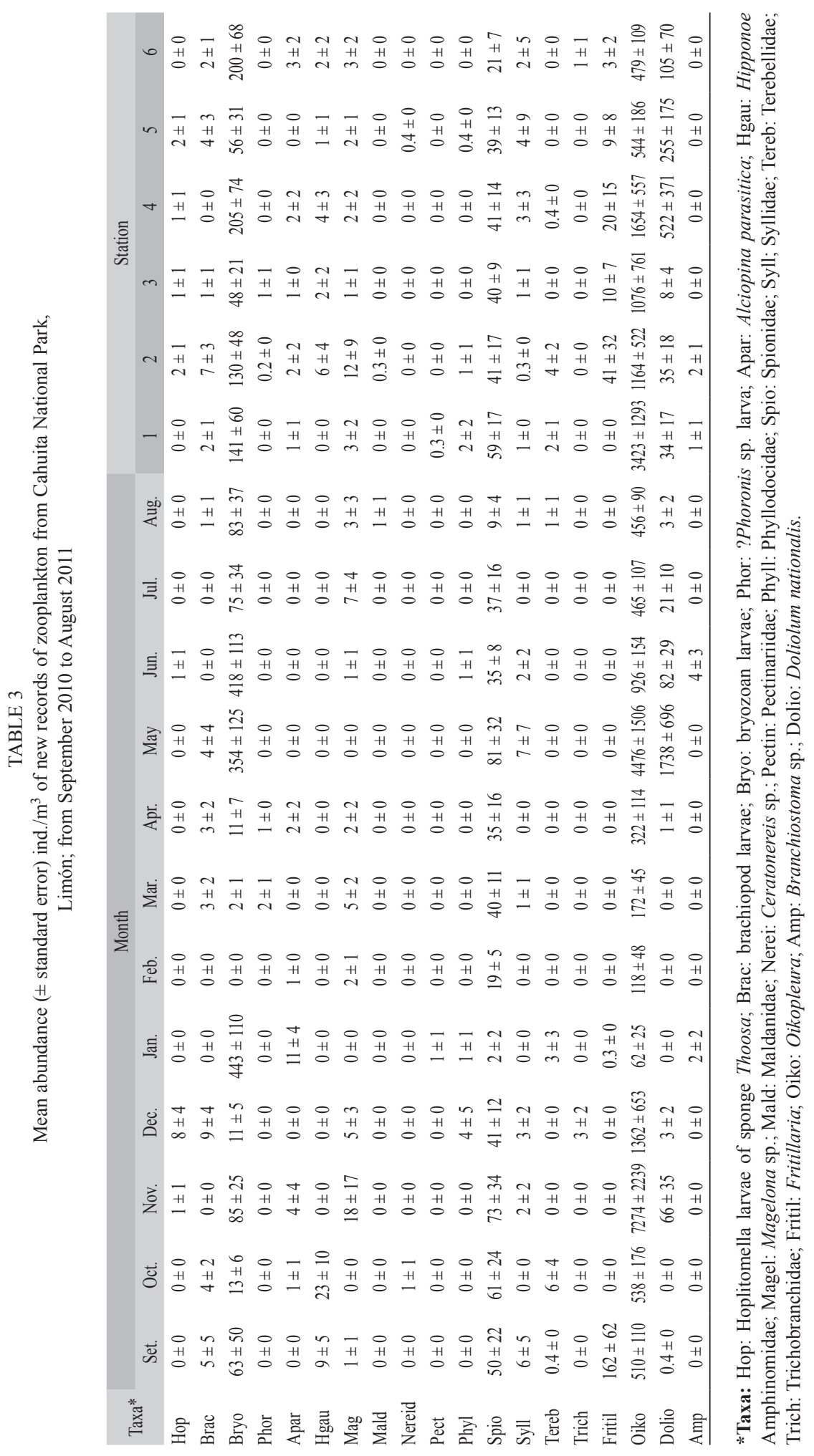


Phylum Brachiopoda Duméril, 1806

Class Lingulata Goryanskij \& Popov, 1985

Lingulata indet.

Locality: all stations, year-round.

Remarks: Specimens having two larval shells and 13 cirri were similar to the larvae of Lingula sp. (Pennington \& Stricker, 2002). This genus has been reported for the Caribbean of Colombia Caribbean (Ávila-de Tábares et al., 2007). Emig (2009a) mentions that only Liothyrella moseleyi (Davidson, 1878) member of the Class Rhynchonellata has been found offshore of Martinique, which makes the specimen of this study the first record of lingulate brachiopods for the Caribbean coast of Central America.

Phylum Bryozoa Ehrenberg, 1831

Class Gymnolaemata Allman, 1856

Gymnolaemata indet.

Locality: all stations, year-round.

Remarks: Cyphonautes larvae belonging to the gymnolaemate bryozoans were found in all the stations in most of the months sampled. These larvae have a lateral compressed triangular body bearing an apical sense organ with few cilia and a ciliated corona on the opposite side (Temkin \& Zimmer, 2002). Ávila-de Tábares et al. (2007) also reported cyphonautes larvae for the Colombian Caribbean.

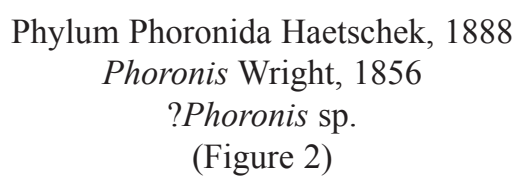

Locality: Puerto Vargas, Shallow patch (St.3): Mar 2011; Deep patch (St.2): Apr 2011.

Remarks: The actinotroch larva from Cahuita has distinct pre-oral lobe, larval tentacles and the stomach diverticulum matching the larva of Phoronis sp. described by Ávila-de Tábares, Martínez-Ramírez, \& Franco-Herrera (2007) for the Caribbean coast of Colombia. Emig (2009b) confirmed the presence of three species of Phoronis from the Caribbean coast of Panama: Phoronis hippocrepia Whrigth, 1856, Phoronis muelleri Selys-Longchamps, 1903

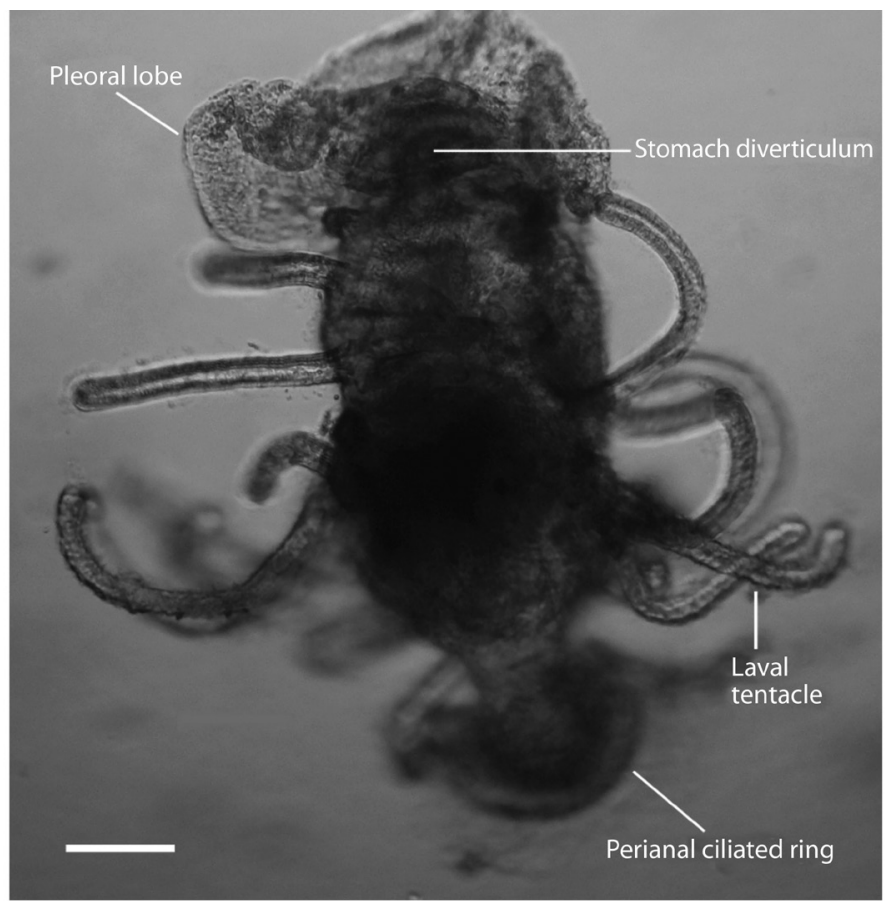

Fig. 2. Actinotroch larva of ?Phoronis sp. found at Cahuita's coral reef. Scale bar: $100 \mu \mathrm{m}$. 
and Phoronis psammophila Cori, 1889. Specimens from Cahuita match with the description of Actinotrocha sabatieri (Roule, 1896) larvae of $P$. psammophila. These specimens are the second report of phoronids for Costa Rican waters after the finding of the adult Phoronopsis albomaculata Gilchrist, 1907 in Isla del Coco, Pacific of Costa Rica (Dean, SibajaCordero, \& Cortés, 2010).

Phylum Annelida Lamarck, 1809

Class Polychaeta Grube, 1850

Family Alciopidae Ehlers, 1864

Alciopina Clapèrede \& Panceri, 1867

Alciopina parasitica Clapèrede \& Panceri, 1867

Locality: Puerto Vargas, Deep patch (St.2): Nov 2010. Outer crest (St.4): Nov 2010 (MZ-UCR 291-01).

Remarks: The specimens have folliaceous parapodia cirri, with acicular simple, capillary chaetae. Chetigerous lobes absent (Støp-Bowitz, 1996; Fernández-Álamo, 2009). This holoplanktonic species is distributed in the Atlantic Ocean, and Indo- Pacific region (Fernández-Álamo, 2009). In the Caribbean Sea, the first record was for the Yucatan Peninsula (Jiménez-Cueto \& Suárez-Morales, 2008). Later, Díaz, Radha, Liñero-Arana, \& Marín (2009) reported this species in Venezuela, but this study is the first report for the Caribbean of Central America.

Family Amphinomidae Savigny in Lamarck, 1818

Hipponoe Audouin \& Milne Edwards, 1830

Hipponoe gaudichaudi Audouin \& Milne Edwards, 1830

Locality: all stations: Sep and Nov 2010; except for Puerto Vargas, Inner Crest (St.1) (MZ-UCR 297-01).

Remarks: This species is recognized by the absence of a caruncle (fleshy outgrowth of the nuchal organs in the prostomium) and neurochaetae with simple hooks (Yáñez-Rivera, 2009). Frequently found in floating $\operatorname{logs}$ or within the valves of the barnacles of the genus
Lepas (Núñez, Riera, \& Brito, 2010). That is the reason why Moore (1903) considered it a pelagic species.

$$
\begin{gathered}
\text { Family Magelonidae } \\
\text { Cunningham \& Ramage, } 1888 \\
\text { Magelona Müller, } 1858 \\
\text { Magelona } \text { sp. }
\end{gathered}
$$

Locality: all stations, year-round except Oct 2010, Jan and May 2011 (MZ-UCR 291-01).

Remarks: This larva presents long, coiled and flexible prototrochal tentacles (Plate \& Husemann, 1994). It has acharacteristic flat, shovel-shaped prostomium and dentate hooded hooks (Hernández-Alcántara \& SolísWeiss, 2009).

Seven species have been reported for the Caribbean (Salazar-Vallejo, 1996). Magelona pettiboneae Jones, 1963 and Magelona riojai Jones, 1963 reported from Belize, are the nearest species to Costa Rica (Dean, 2009).

\section{Family Maldanidae Malmgren, 1867 Maldanidae indet.}

Locality: Puerto Vargas, Deep patch (St.2): Aug 2011 (MZ-UCR 299-01).

Remarks: This family has a truncate anterior end, with a head consisting of keel between two nuchal slits (Salazar-Vallejo \& Díaz-Díaz, 2009). 18 genera and 24 species are reported for the Caribbean (Salazar-Vallejo, 1996). Adults of Clymenella sp. and Isocirrus longiceps (Moore, 1923) have been found in the Gulf of Nicoya, Pacific coast of Costa Rica (Dean, 2009).

$$
\begin{gathered}
\text { Family Paraonidae Cerruti, } 1909 \\
\text { Aricidea Webster, } 1879 \\
\text { Aricidea (Acmira) simplex Day, } 1963 \\
\text { (Figure 3A) }
\end{gathered}
$$

Locality: Puerto Vargas, Shallow patch (St.3): Oct 2010 (MZ-UCR 285-01).

Remarks: Adult with a median antenna in the prostomium, without eyes. Branchiae starts 

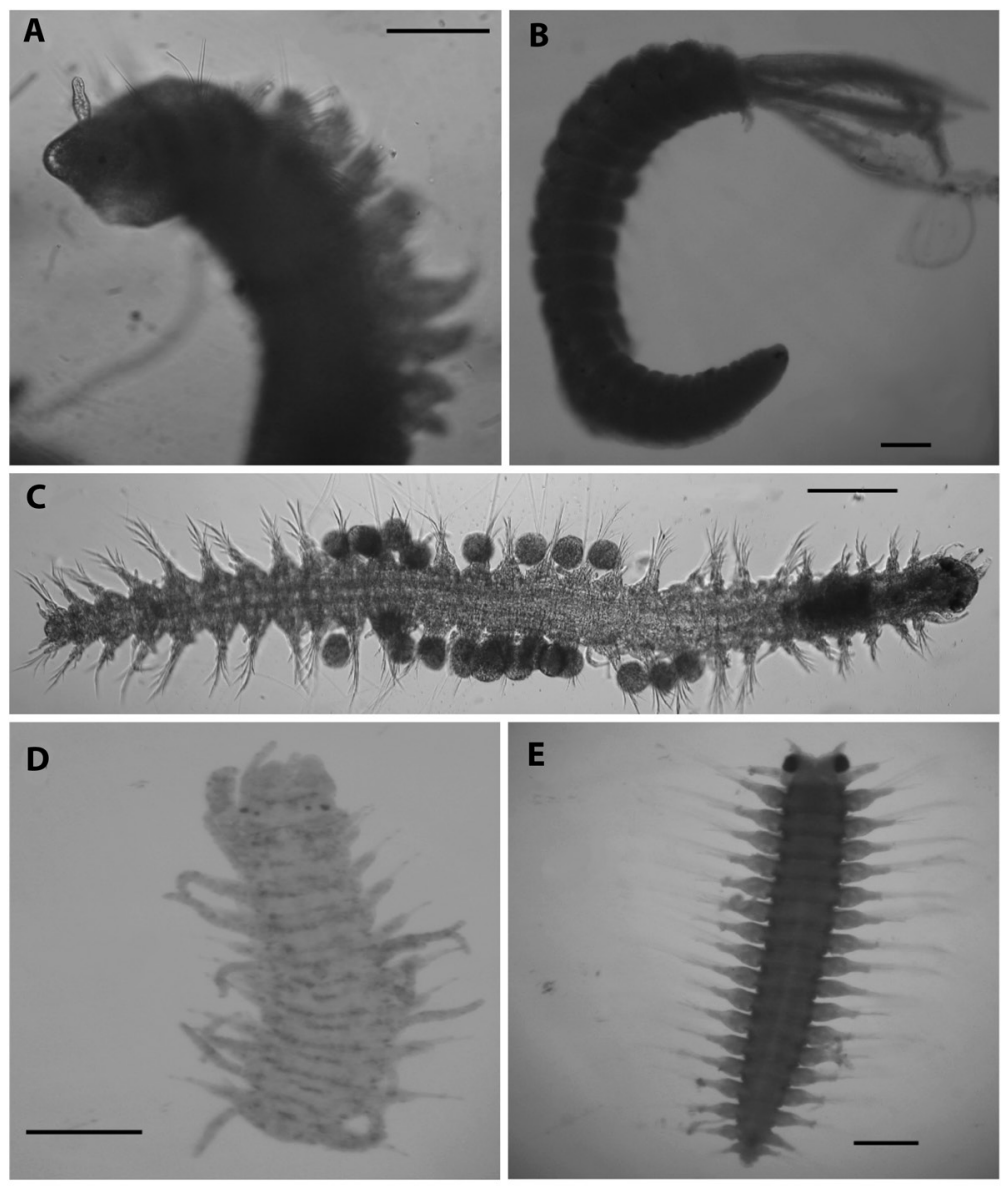

Fig. 3. Diversity of polychaetes found in zooplankton tows at Cahuita's coral reef; A: Aricidea (Acmira) simplex Day, 1963; B: Parasabella jamaicensis Augener, 1924; C: Exogone (Exogone) breviantennata Eisig, 1870; D: Syllis cf. armillaris Müller, 1776; E: Trypanosyllis parvidentata Perkins, 1981. Scale bars: (A, C-E), $100 \mu \mathrm{m}$; ( B) $500 \mu \mathrm{m}$.

at the $4^{\text {th }}$ setiger. Winged capillary chaetae on the anterior, and without wings on the posterior. Neurochaetae with wide hooks, curved spiniform (Solís-Weiss, 1996). This species had been recorded for deep benthic waters from Venezuela (Bone \& Chollett, 2005).

Family Pectinariidae Quatrefages, 1866 Pectinariidae indet.

Locality: Puerto Vargas, Inner crest (St.1): Jan 2011 (MZ-UCR 292-01).

Remarks: Specimens with tusk-shape tubes, open in both sides (Londoño-Mesa, 2009a). This characteristic is present also in the nectochaete (Plate \& Husemann, 1994). Six species in two genera are reported for the Greater Caribbean (Londoño-Mesa, 2009a).

Family Phyllodocidae Örsted, 1843

Sige Malmgren, 1865

?Sige sp.

Locality: Puerto Vargas, Inner crest (St.1): Dec 2010; Perezoso River: Jan 2011 MZ-UCR 298-01).

Remarks: The specimens are in the metatrochophore stage with segment 1 fused to segment 2 and showing flat ventral tentacular cirri. Only Sige belizensis Eibye-Jacobsen, 
1992 for Belize, Sige parvicirrus (Perkins, 1984) for Florida, and Sige macroceros orientalis Imajima and Hartman, 1964 have been reported for the Greater Caribbean (SalazarVallejo, 1996; Perkins, 1998; Dean, 2012).

Family Sabellidae Latreille, 1825

Parasabella Bush, 1905

Parasabella jamaicensis Augener, 1924

(Figure 3B)

Locality: Puerto Vargas, Shallow patch (St.3): Nov 2010 (MZ-UCR 286-01).

Remarks: Thoracic uncini with avicular appearance. Abdomen with a row of neuropodial chaetae, thoracic notochaetae broadly hooded. Radioles without ocelli (Tovar-Hernández \& Salazar-Vallejo, 2006). Fewer radioles and abdominal chaetigers on Cahuita's specimen indicate that it is a juvenile, in comparison with the adult found by Dean (2017).

Family Spionidae Grube, 1850

Spionidae spp. indet.

Locality: all stations, year-round.

Remarks: Trochophores and metatrochophores are frequently found in zooplankton surveys, because a planktotrophic or lecithotrophic larvae are present in most of the reproductive strategies of Spionidae (Wilson, 1991). Most of the nectochaetes have two pair of short or long palps and two or three pair of eyes (Plate \& Husemann 1994). Scolelepis (Scolelepis) squamata (O. F. Müller, 1806) was recorded for Cahuita, and it is the only spionid for the Caribbean coast of Costa Rica (Dean, 2009), in overall of 25 genera and 56 species recorded for the Greater Caribbean (DelgadoBlas, 2009).

Family Syllidae Grube, 1850

Subfamily Autolytinae Langerhans, 1879 Autolytinnae indet.

Locality: Puerto Vargas, Inner crest (St.1): Feb 2011; Suarez River (St. 6): Feb 2011 (MZUCR 293-01).
Remarks: Palps not so well developed. Head appendages not articulated. Ventral cirri absent (Góngora-Garza, 2009). Autolytoids are rare in the plankton, most in the form of stolons. The collected specimen belongs to a male stolon or "polybostrichus", with a bifid antennae on the front of the head and three posterior horns (Franke, 1999). Allen (1957) found both male and female stolons at La Parguera, Puerto Rico. There are three genera and $11 \mathrm{spp}$. of this subfamily in the Greater Caribbean (GóngoraGarza, 2009).

Subfamily Eusyllinae Malaquin, 1893

Odontosyllis Claparède, 1863

Odontosyllis sp.

Locality: Puerto Vargas, Shallow patch (St.3): Mar 2011 (MZ-UCR 296-01).

Remarks: Eversible pharynx, armed without a complete trepan or a median dorsal tooth. Eight species are recorded for the Greater Caribbean (Góngora-Garza, 2009; Dean, 2012). Odontosyllis luminosa San Martín, 1990 and Odontosyllis twincayensis Russell, 1989 from Belize, are the closest to the Caribbean coast of Costa Rica (Dean, 2009).

Subfamily Exogoninae Langerhans, 1879 Exogone Örsted, 1845

Exogone (Exogone) breviantennata

Hartmann-Schröeder, 1959

(sensu Zottoli and Long, 2000)

(Figure 3C)

Locality: Perezoso River (St.5): Nov 2010 (MZ-UCR 288-02).

Remarks: The specimen is an epigamic female incubating eggs, and presents a digitiform antenna and rounded acicula (RuízRamírez \& Salazar-Vallejo, 2001). The species has been previously reported as an adult for Cuba, Florida and Venezuela (San Martín, 1991; San Martín \& Bone, 2001); in Costa Rica from the Gulf of Nicoya and Isla del Coco (Dean, 2009; Dean, Sibaja-Cordero, \& Cortés, 2012). 
Subfamily Syllinae Rioja, 1925

Syllis Lamarck, 1818

Syllis cf. armillaris (O. F. Müller, 1776)

(Figure 3D)

Locality: Suárez River (St.6): Dec 2010 (MZ-UCR 289-01).

Remarks: Median antenna with nine articles, lateral antenna with 13 articles and dorsal cirri at the mid-body with 10 articles. With an acuminate aciculae, matching Góngora-Garza (2009) and Liñero-Arana \& Díaz-Díaz (2011). Found as commensal of hermit crabs in the Mediterranean Sea (López, Britayev, Martin, \& San Martín, 2001).

Trypanosyllis Claparède, 1864

Trypanosyllis parvidentata Perkins, 1981

(Figure 3E)

Locality: Puerto Vargas, Shallow patch (St.3): Nov 2010, Jan 2011; Inner crest (St.1) and Deep patch (St.2): Jan 2011 (MZ-UCR 290-01).

Remarks: With a trepan consisting of 10 small teeth, and one single-median large tooth (Góngora-Garza, 2009). It has been found in Mexico (Granados-Barba, Solíz-Weiss, TovarHernández, \& Ochoa-Rivera, 2003) and Venezuela (Liñero-Arana \& Díaz-Díaz, 2011)

Family Terebellidae Malmgren, 1867 Terebellidae indet.

Locality: Puerto Vargas, Inner crest (St.1): Oct 2010, Jan and Aug 2011; Deep patch (St.2): Sep and Oct 2010 and Jan 2011; Outer crest (St.4): Aug 2011 (MZ-UCR 295-01).

Remarks: With one or more stout anterior tentacles (Cumrine, 2001). Thoracic and abdominal uncini with short shaft (Harris, de León-González, \& Salazar-Vallejo, 2009). Nineteen genera and 33 species have been reported for the region (Londoño-Mesa, 2009b).
Family Trichobranchidae Malmgren, 1866

Trichobranchidae indet.

Locality: Suáres River (St.6): Dec 2010 (MZ-UCR 291-02).

Remarks: Thoracid uncini with long shaft, abdominal unicni with short shaft (Harris et al. 2009). Two genera and five species have been reported for the Caribbean region (Solís-Weiss, Londoño-Mesa, \& HernándezAlcántara, 2009). Rouse \& Pleijel (2001) and Garrafoni \& Lana (2008) consider Trichobranchidae as a subfamily of Terebellidae.

Phylum Chordata Haeckel, 1874

Subphylum Cephalochordata Owen, 1846

Class Leptocardii

Family Branchiostomidae

Branchiostoma Bonaparte, 1941

Branchiostoma sp.

Locality: Puerto Vargas, Deep patch (St.2): Jan 2011, Jun 2011; Outer crest (St.4): Jan 2011; Inner crest (St.1): Jun 2011.

Remarks: The presence of a gonad on each lateral site of the body confirms that the specimens belong to Branchiostoma (Poss \& Boschung, 1996). However, the lack of well-defined myotomes or segments of the dorsal storage chamber, reflects their juvenile stage, which inhibits the clarification to a species level.

Subphylum Tunicata Lamarck, 1816

Class Appendicularia

Order Copelata

Family Fritillariidae Lohman, 1915

Fritillaria Fol, 1872

Fritillaria formica Fol, 1872

Locality: all stations: Set 2010.

Remarks: Strongly bend trunk. Length up to $2 \mathrm{~mm}$. With two lateral lobes and one median lobe on the mouth (Esnal, 1999). At 
Chinchorro Bay, Caribbean of Mexico, is the second most abundant species of appendicularians after Oikopleura (Coecaria) longicauda (Vogth, 1864) (Castellanos-Osorio 2003). This is the first record of the family for the Caribbean coast of Central America.

\section{Fritillaria haplostoma Fol, 1872}

Locality: all stations: Set 2010.

Remarks: Slightly bend trunk, not as strong or long as Fritillaria formica. No lobes on the mouth (Esnal, 1999). On the southern Gulf of Mexico, it can represent up to $49 \%$ of appendicularian abundance (Flores-Coto, San Vicente-Añorve, \& Sánchez-Ramírez, 2010).

\section{Family Oikopleuridae Lohman, 1915 Oikopleura Mertens, 1830 \\ Oikopleura (Coecaria) longicauda (Vogth, 1864)}

\section{Locality: all stations, year-round.}

Remarks: Specimens presented a compact trunk and muscular tail. Postcardial caecum joins the genital wall of the esophagus (Esnal, 1999). The most abundant appendicularian in the Caribbean (Castellanos, Suárez-Morales, \& Morales-Ramírez, 2009). As well as the Fritillaria species, they are found throughout the Greater Caribbean and the South Atlantic (Esnal, 1999), but this is the first report for the Caribbean of Central America, after the genus Oikopleura was reported in the San Blas Archipielago in Panama (D'Croz, Robertson, \& Martínez, 1999).

\section{Class Thaliacea Nielsen, 1995 \\ Order Doliolida \\ Family Doliolidae \\ Doliolum Quoy \& Gaimard, 1834 \\ Doliolum nationalis Borgert, 1893}

Locality: all stations; September and November 2010, from April to August 2011.

Remarks: With a barrel form, Thaliacea is characterized by an alternation of asexual (oozooids) and sexual (blastozooids) generations (Esnal, 1996). Oozooids have nine muscular bands and blastozooids have eight, in the doliolids (Esnal \& Daponte, 1999). In Cahuita, both generations of Doliolum nationalis were found. Specimens have a gill-septum that extended from the muscular band II to the muscular band V and VI (Bone, 1998).

Esnal \& Daponte (1999) mentioned a neritic distribution for the salp $D$. nationalis. Specimens of Doliolum have been found in coral reefs of Barbados (Lewis \& Fish 1969; Moore \& Sander, 1976), Venezuela (Casanova, Zoppi de Roa, \& Montiel, 2007), offshore of Jamaica (Moore \& Sander 1976, 1979). Doliolum nationalis have been reported for Port Royal Cays in Jamaica (Webber, Roff, Chisholm, \& Clarke, 1996). This is the first record of this species for Central American waters, after specimens of Doliolum sp. was reported in Isla del Coco, Pacific of Costa Rica (Morales-Ramírez, 2008).

\section{DISCUSSION}

The Caribbean coast of Costa Rica does not have as many species as other countries in the Caribbean and Western Atlantic (Cortés \& Wehrtmann, 2005). However, it is considered the most diverse country of the region, in terms of the numbers of species related to the coastline length (Wehrtmann, Cortés, \& EcheverríaSáenz, 2009).

An example of this diversity is shown here with new records of a variety of developmental stages of important biogenic architects of the coral reef (Cocito, Ferdeghini, \& Sgorbini, 2001), such as sponges, polychaetes and "lophophorates". In addition, unidentified larvae of echinoderms and mollusks were a large year-around component of Cahuita's zooplankton (Morales-Ramírez \& Murillo, 1996). Apart from the meroplantonick forms, 13 new records of copepods (Morales-Ramírez, Suárez-Morales, Corrales-Ugalde, \& EsquivelGarrote, 2014), and the description of two new species of monstrilloid copepods: Monstrillopsis cahuitae Suárez-Morales \& Carrillo, 2013 and Cymbasoma alvaroi Suárez-Morales 
\& Carrillo, 2013, were previously reported (Suárez-Morales, Carrillo-Baltodano, \& Morales-Ramírez, 2013). Moreover, although highly abundant, only two records at the specific level of pelagic chordates were reported for the Caribbean of Costa Rica (Castellanos et al., 2009) until the present study. Reported here are four species of tunicates and one species of cephalochordates, which is likely an underestimate of their diversity and more species could be found in oceanic waters of the region.

Considering polychaetes, Miloslavich et al. (2010; Table S5) showed Costa Rica as having the lowest richness on the South-Western Caribbean ecoregion (the other four are: Western Caribbean, Southern Caribbean, Greater Antilles and Eastern Caribbean), the ecoregion with the lowest polychaete richness. This trend was also seen by Dean $(2009,2012,2017)$ who argued that this discrepancy is due to the low sampling effort especially along the Caribbean coasts of Nicaragua and Costa Rica.

In the present study, we increase the knowledge concerning polychaete identification, but five specimens where only identified to the family level due to the lack of keys or diagnostic characters for the larval stages. Previously, 75 species across 22 families were reported from the Caribbean of Costa Rican (Dean, 2009, 2012, 2017). Glycera oxycephala Ehlers, 1887, however, was reported for Moín, and have not been reported for Cahuita (Böggemann, 2002). The new records found in the present study raises the diversity of polychaetes up to 29 families, 74 genera and 81 species for the Caribbean of Costa Rica. These figures remain an underestimate, and a more careful revision of deposit material and adult surveys will reveal a larger amount of new reports (Bogantes-Aguilar, 2014).

The polychaetes reported here, either to family, generic or specific level have been reported for the Caribbean coasts of Mexico (Salazar-Vallejo, 1996), Belize (Young \& Young, 1982), Panama (Fauchald, 1977), Venezuela (Liñero-Arana \& Díaz-Díaz, 2011) and other countries of the region (Dean, 2012). This is expected, since the Caribbean region is connected by major currents, from southeast to northwest, in the Greater and Lesser Antilles, and to the opposite direction in the southern Central American coast (Centurioni \& Niiler, 2003). This means that many coral reef invertebrates and fishes with a planktonic larva, could be distributed and shared throughout the region (Warner \& Goodbody, 2005; Salas, MolinaUreña, Walter, \& Health, 2010), emphasizing the need for more studies of meroplankton and their role in population recruitment in the Caribbean of Central America.

Morales-Ramírez \& Murillo (1996) mentioned that Cahuita might have low meroplankton diversity due to the degradation of the coral reef at Cahuita (Cortés et al., 2010). In addition, warmer waters during the 1982-1983 El Niño event (Cortés, Murillo, Guzmán, \& Acuña, 1984) could have caused a mismatch between the availability of phytoplankton (González et al., 2000) and the right time for spawning of many sessile invertebrates (Przeslawski, Ahyong, Byrne, Wörheides, \& Hutchings, 2008). Nevertheless, with the findings of the current study, including all the larval forms of echinoderms, the three larvae of lophoporates clades, and many polychaetes forms, we showed that Cahuita's coral reef may hold more diversity than previously thought. Even with a great diversity of marine invertebrate larvae, recruitment studies are still lacking to understand the population dynamics of the reef (Alvarado, Cortés, \& Salas, 2004).

The present study fills a gap in the knowledge of planktonic communities of the Caribbean coast of Costa Rica (Cortés \& Wehrtmann, 2005). Using the same methodology as Morales-Ramírez \& Murillo (1996) with the inclusion of two more stations (Carrillo-Baltodano \& Morales-Ramírez, 2016) had allowed the evaluation of the zooplankton in terms of abundance, biomass and diversity after 25 years. Many of the reports shown here, were present only at one station in a single month, while other were present yearround. The spatio-temporal dynamics of their presence correlate with abiotic variables during the year sampled (Carrillo-Baltodano \& 
Morales-Ramírez, 2016). Looking into the zooplankton is an essential approach to studying not only the diversity, but also the trophic, biogeochemical and ecosystemic dynamics of the coral reef. The relevance of species or groups diversity exceeds the value of the taxonomic inventory, because it enhances the possibility of better understanding the ecological goods and services (e.g. tourism, fisheries) that it can provide, leading us to an improvement in its management and conservation (Mumby et al., 2008; Miloslavich et al., 2010).

\section{ACKNOWLEDGMENTS}

We thank Marco Corrales for the identification of the chordates. All sample collections were carried out with the permission from $\mathrm{La}$ Amistad-Caribe Conservation Area and Cahuita National Park administration. Funding was provided by the Vicerrectoría de Investigación, Universidad de Costa Rica (J.C. grant number 808-B2-044).

\section{RESUMEN}

Nuevos reportes de invertebrados planctónicos marinos de la costa Caribe de Costa Rica: El arrecife coralino del Parque Nacional Cahuita en el Caribe de Costa Rica representa un importante y biodiverso ecosistema marino. Sin embargo, la mayoría de la diversidad reportada es el resultado de estudios del bentos, con una minoría de estudios pelágicos. Un muestreo mensual del zooplancton arrecifal fue realizado entre Septiembre 2010 y Agosto 2011. Se encontraron 32 reportes nuevos para el Caribe de Costa Rica, siete para Costa Rica y 16 para el Caribe de Centroamérica. Estos reportes incluyen una larva hoplitomela de la esponja Thoosa sp.; estadios larvales de los tres lofoforados; siete familias, cinco géneros y seis especies de poliquetos; un juvenil del anfioxo Branchiostoma (Filo Chordata, Subfilo Cephalochordata); y cuatro cordados pelágicos. Una comprensión del zooplancton es un enfoque esencial para el estudio de la diversidad, y a su vez aumenta la posibilidad de entender mejor los bienes y servicios ecológicos que el arrecife coralino puede proveer.

Palabras clave: arrecife coralino; larvas de invertebrados marinos; Cahuita; poliquetos; zooplancton

\section{REFERENCES}

Allen, M. J. (1957). The breeding of polychaetous annelids near Parguera, Puerto Rico. Biological Bulletin, 113, 49-57.

Alvarado, J. J., Cortés, J., \& Salas, E. (2004). Population densities of Diadema antillarum Philippi at Cahuita National Park (1977-2003), Costa Rica. Caribbean Journal of Science, 40, 257-259.

Angel, M. V. (1993). Biodiversity of the pelagic ocean. Conservation Biology, 7, 760-772.

Ávila-de Tabarés, G., Martínez-Ramírez, O., \& FrancoHerrera, A. (2007). Larvas planctónicas de lofoforados en la Bahía de Gaira, Magdalena, Caribe colombiano. Boletín de Investigaciones Marinas y Costeras, 36, 327-332.

Bautista-Guerrero, E., Carballo J. L., \& Maldonado, M. (2010). Reproductive cycle of the coral-excavating sponge Thoosa mismalolli (Clionaidae) from Mexican Pacific coral reefs. Invertebrate Biology, 129, 285-296.

Bogantes-Aguilar, V. E. (2014). Poliquetos (Annelida: Polychaeta) del Parque Nacional Cahuita, Limón, Costa Rica. (Licenciatura's thesis). San José, Costa Rica: Universidad de Costa Rica.

Böggeman, M. (2002). Revision of the Glyceridae Grube 1850 (Annelida: Polychaeta). Abhandlungen der Senckenbergischen Naturforschenden Gesellschaft, 555, 1-249.

Bone, Q. (1998). The Biology of Pelagic Tunicates. New York: Oxford University Press.

Bone, D., \& Chollett, I. (2005). Biodiversidad de anélidos poliquetos de aguas profundas, Venezuela. In G. Gómez, M. Capaldo, C. Yanez \& A. Martín (Eds.). Frente Atlántico Venezolano Investigaciones Geoambientales: Ciencias Ambientales (pp. 65-81). Venezuela: Corporación Venezolana de Petróleo.

Bucklin, A., Nishida, S., Schnack-Schiel, S., Wiebe, P. H., Lindsay, D., Machida, R. J., \& Copley, N. J. (2010). A census of zooplankton of the global ocean. In A. D. McIntyre (Ed.). Life in the World's Oceans: Diversity, Distribution, and Abundance (pp. 247-265). Oxford, United Kingdom: Blackwell Publishing.

Carrillo-Baltodano, A., \& Morales-Ramírez, A. (2016). Changes in abundance and composition of a Caribbean coral reef zooplankton community after 25 years. Revista de Biología Tropical, 64, 1029-1040.

Casanova, E., Zoppi de Roa, E., \& Montiel, E. (2007). Caracterización espacial y temporal del zooplancton 
en el archipiélago Los Roques, Venezuela. Boletín del Instituto Oceanográfico de Venezuela, 46, 51-65.

Castellanos, I. (2003). Appendicularians (Tunicata) of Banco Chinchorro, Caribbean Sea. Bulletin of Marine Science, 73, 133-140.

Castellanos, I., Suárez-Morales, E., \& Morales-Ramírez, A. (2009). Appendicularians (Urochordata). In I. S. Wehrtmann \& J. Cortés (Eds.). Marine Biodiversity of Costa Rica, Central America (Text: pp. 445-453, Species list: Compact Disk: p. 411). Berlin, Germany: Springer + Business Media B.V.

Centurioni, L. R., \& Niiler, P. P. (2003). On the surface currents of the Caribbean Sea. Geophysical Research Letters, 30, 1-4.

Cocito, S., Ferdeghini, F., \& Sgorbini, S. (2001). Bioconstructions promote biodiversity: lessons from bryozoans and other invertebrates. Biologica Marina Mediterranea, 8, 175-180.

Cortés, J., \& Jiménez, C. (2003). Past, present and future of coral reefs of the Caribbean coast of Costa Rica. In J. Cortés (Ed.). Latin American Coral Reefs (pp. 223-239). Amsterdam: Elsevier Science B.V.

Cortés, J., \& Risk, M. J. (1985). A reef under siltation stress: Cahuita, Costa Rica. Bulletin of Marine Science, 36, 339-356.

Cortés, J., \& Wehrtmann, I. (2005). Costa Rica. In P. Miloslavich \& E. Klein (Eds.). Caribbean Marine Biodiversity: The Known and the Unknown (pp. 169-179). Pennsylvania, USA: DEStech Publications.

Cortés, J., Murillo, M. M., Guzmán, H. M., \& Acuña, J. (1984). Pérdida de zooxantelas y muerte de corales y otros organismos arrecifales en el Caribe y Pacífico de Costa Rica. Revista de Biología Tropical, 32, 227-232.

Cortés, J., Van der Hal, N., \& Van Soest, R. W. M. (2009). Sponges. In I. S. Wehrtmann \& J. Cortés (Eds.). Marine Biodiversity of Costa Rica, Central America (Text: pp. 137-142, Species List: Compact disk: pp. 83-93). Berlin, Germany: Springer + Business. Media B.V.

Cortés, J., Jiménez, C. E., Fonseca, A. C., \& Alvarado, J. J. (2010). Status and conservation of coral reefs in Costa Rica. Revista de Biología Tropical, 58 (Suppl. 1), 33-50.

Crumrine, L. (2001). Polychaeta. In A. Shanks (Ed.). An Identification Guide to the Larval Marine Invertebrates of the Pacific Northwest (pp. 39-77). Oregon, USA: Oregon State Univ. Press.

D’Croz, L., Robertson, D. R., \& Martínez, J. A. (1999). Cross-shelf distribution of nutrients, plankton, and fish larvae in the San Blas Archipielago, Panamá. Revista de Biología Tropical, 47, 203-215.
Dean, H. K. (2009). Polychaetes and Echiurans. In I. S. Werhtmann \& J. Cortés (Eds.). Marine Biodiversity of Costa Rica, Central America (Text: pp. 181-191, Species List: Compact disk: pp. 122-159). Berlin, Germany: Springer+ Business. Media B.V.

Dean, H. K. (2012). A literature review of the Polychaeta of the Caribbean Sea. Zootaxa, 3596, 1-86.

Dean, H. K. (2017). Some intertidal and shallow water polychates of the Caribbean coasts of Costa Rica. Revista de Biología Tropical, 65, 127-152.

Dean, H. K., Sibaja-Cordero, J. A., \& Cortés, J. (2010). Occurrence of the Phoronid Phoronopsis albomaculata in Cocos Island, Costa Rica. Pacific Science, 64, 459-462.

Dean, H. K., Sibaja-Cordero, J. A., \& Cortés, J. (2012). Polychaetes (Annelida: Polychaeta) of Parque Nacional Isla del Coco, Pacific Costa Rica. Pacific Science, 66, 347-386.

Delgado-Blas, V. H. (2009). Spionidae Grube, 1850. In J. A. de León-González, J. R. Bastida-Zavala, L. F. Carrera-Parra, M. E. García-Garza, A. Peña-Rivera, S. I. Salazar-Vallejo \& V. Solís-Weiss (Eds.). Poliquetos (Annelida: Polychaeta) de México y América Tropical (pp. 589-614). Monterrey, México: Universidad Autónoma de Nuevo Léon.

Díaz, O. F., Radha, E., Liñero-Arana, I., \& Marín, B. (2009). Poliquetos holoplanctónicos (Annelida: Polychaeta) de la plataforma del Atlántico venezolano. Ciencia y Mar, 13, 15-26.

Emery, A. R. (1968). Preliminary observation on coral reef plankton. Limnology and Oceanography, 13, 293-303.

Emig, C. C. (2009a). Brachiopods. In I. S. Wehrtmann \& J. Cortés (Eds.). Marine Biodiversity of Costa Rica, Central America (Text: pp. 417-420, Species list: Compact Disk: pp. 389-391). Berlin, Germany: Springer + Business Media B.V.

Emig, C.C. (2009b). Phoronids. In I. S. Wehrtmann \& J. Cortés (Eds.). Marine Biodiversity of Costa Rica, Central America (Text: pp. 409-411, Species list: Compact Disk: pp. 385-388). Berlin, Germany: Springer + Business Media B.V.

Esnal, G. B. (1996). Thaliacea y Appendicularia. In R. Gasca \& E. Suárez (Eds.). Introducción al estudio del zooplancton marino (pp. 597-630). México: El Colegio de la Frontera Sur (ECOSUR) / CONACYT.

Esnal, G. B. (1999). Appenciularia. In D. Boltovskoy (Ed.). South Atlantic Zooplankton (pp. 1375-1399). Leiden: Backhuys Publishers.

Esnal, G. B., \& Daponte, M. C. (1999). Doliolida. In D. Boltovskoy (Ed.). South Atlantic Zooplankton (pp. 1409-1421). Leiden: Backhuys Publishers. 
Fauchald, K. (1977). Polychaetes from intertidal areas in Panama, with a review of previous shallow-water records. Smithsonian Contributions to Zoology, 221, $1-75$.

Fernández-Álamo, M. A. (2009). Alciopidae Ehlers, 1864. In J. A. de León-González, J. R. Bastida-Zavala, L. F. Carrera-Parra, M. E. García-Garza, A. Peña-Rivera, S. I. Salazar-Vallejo \& V. Solís-Weiss (Eds.). Poliquetos (Annelida: Polychaeta) de México y América Tropical (pp. 41-50). Monterrey, México: Universidad Autónoma de Nuevo Léon.

Fisher, R., O’Leary, R. A., Low-Choy, S., Mengersen, K., Knowlton, N., Brainard, R. E., \& Caley, J. (2015). Species richness on coral reefs and the pursuit of convergent global estimates. Current Biology, 25, 500-505.

Flores-Coto, C., Sanvicente-Añorve, L., \& Sánchez-Ramírez, M. (2010). Appendicularian distribution and diversity in the Southern Gulf of Mexico. Revista Mexicana de Biodiversidad, 81, 123-131.

Fonseca, A. C., \& Gamboa, C. (2003). A rapid assessment at Cahuita National Park, Costa Rica, 1999. (Part 2: reef fishes). Atoll Research Bulletin, 496, 258-266.

Fonseca, A. C., Salas, E., \& Cortés, J. (2006). Monitoreo del arrecife coralino Meager Shoal, Parque Nacional Cahuita, Costa Rica (sitio CARICOMP). Revista de Biología Tropical, 54, 755-763.

Franke, H. D. (1999). Reproduction of the Syllidae (Annelida: Polychaeta). Hydrobiologia, 402, 39-55.

Garrafoni, A. R. S., \& Lana, P. C. (2008). Phylogenetic relationships within the Terebellidae (Polychaeta: Terebellida) based on morphological characters. Invertebrate Systematic, 22, 605-626.

Glynn, P. W. (1973). Ecology of a Caribbean coral reef The Porites reef-flat biotope: Part II. Plankton community with evidence for depletion. Marine Biology, $22,1-21$.

Góngora-Garza, G. (2009). Syllidae Grube, 1850. In J. A. de León-González, J. R. Bastida-Zavala, L. F. Carrera-Parra, M. E. García-Garza, A. Peña-Rivera, S. I. Salazar-Vallejo \& V. Solís-Weiss (Eds.). Poliquetos (Annelida: Polychaeta) de México y América Tropical (pp. 615-639). Monterrey, México: Universidad Autónoma de Nuevo Léon.

González, N. M., Müller-Karger, F. E., Estrada, S. C., Pérez de Los Reyes, R., Río, I. V., Pérez, P. C., \& Arenal, I. M. (2000). Near-surface phytoplankton distribution in the western Intra-Americas Sea: The influence of El Niño and weather events. Journal of Geophysical Research: Oceans (1978-2012), 105, 14029-14043.

Granados-Barba, A., Solís-Weiss, V., Tovar-Hernández, M. A., \& Ochoa-Rivera, V. (2003). Distribution and diversity of the Syllidae (Annelida: Polychaeta) from the Mexican Gulf of Mexico and Caribbean. Hydrobiologia, 496, 337-345.

Harris, L. H., de León-González, J. A., \& Salazar-Vallejo, S. I. (2009). Morfología, métodos, clave para familias y clasificación. In J. A. de León-González, J. R. Bastida-Zavala, L. F. Carrera-Parra, M. E. García-Garza, A. Peña-Rivera, S. I. Salazar-Vallejo \& V. SolísWeiss (Eds.). Poliquetos (Annelida: Polychaeta) de México y América Tropical (pp. 3-32). Monterrey, México: Universidad Autónoma de Nuevo Léon.

Heidelberg, K. B., Sebens, K. P., \& Purcell, J. E. (2004). Composition and sources of near reef zooplankton on a Jamaican forereef along with implications for coral feeding. Coral Reefs, 23, 263-276.

Hernández-Alcántara, P., \& Solís-Weiss, V. (2009). Magelonidae Cunningham \& Ramage, 1888. In J. A. de León-González, J. R. Bastida-Zavala, L. F. CarreraParra, M. E. García-Garza, A. Peña-Rivera, S. I. Salazar-Vallejo \& V. Solís-Weiss (Eds.). Poliquetos (Annelida: Polychaeta) de México y América Tropical (pp. 277-289). Monterrey, México: Universidad Autónoma de Nuevo Léon.

Highsmith, R. C., Lueptow, R. L., \& Schonberg, S. C. (1983). Growth and bioerosion of three massive corals on the Belize barrier reef. Marine Ecology Progress Series, 13, 261-271.

Jiménez-Cueto, S., \& Suárez-Morales, E. (2008). An account of Alciopina, Torrea, and Rhynconereela (Polychaeta: Alciopidae) of the western Caribbean Sea. Belgian Journal of Zoology, 138, 70-80.

Lewis, J. B., \& Fish, A. G. (1969). Seasonal variation of the zooplankton fauna on surface waters entering the Caribbean Sea at Barbados. Caribbean Journal of Science, 9, 1-23.

Liñero-Arana, I., \& Díaz-Díaz, O. (2011). Syllidae (Annelida, Polychaeta) from the Caribbean coast of Venezuela. ZooKeys, 11, 1-28.

Londoño-Mesa, M. H. (2009a). Pectinariidae de Quatrefages, 1866. In J. A. de León-González, J. R. BastidaZavala, L. F. Carrera-Parra, M. E. García-Garza, A. Peña-Rivera, S. I. Salazar-Vallejo \& V. Solís-Weiss (Eds.). Poliquetos (Annelida: Polychaeta) de México y América Tropical (pp. 403-408). Monterrey, México: Universidad Autónoma de Nuevo Léon.

Londoño-Mesa, M. H. (2009b). Terebellidae (Polychaeta: Terebellida) from the Grand Caribbean region. Zootaxa, 2320, 1-93

López, E., Britayev, T. A., Martin, D., \& San Martín, G. (2001). New symbiotic associations involving Syllidae (Annelida: Polychaeta), with taxonomic and biological remarks on Pionosyllis magnifica and Syllis cf. armillaris. Journal of the Marine Biological Association of the United Kingdom, 81, 399-409. 
Maldonado, M., \& Berqquist, P. R. (2002). Phylum Porifera. In C. M. Young, M. A. Sewell \& M. A. Rice (Eds.). Atlas of Marine Invertebrate Larvae (pp. 21-50). London: Academic Press.

Miloslavich, P., Díaz, J. M., Klein, E., Alvarado, J. J., Díaz, C., Gobin, J., ... Ortiz, M. (2010). Marine biodiversity in the Caribbean: regional estimates and distribution patterns. PLoSONE, 5, e11916.

Moore, J. P. (1903). Some pelagic polychaeta to the Woods Hole fauna. Proceedings of the Academy of Natural Sciences of Philadelphia, 55, 793-801.

Moore, E. A., \& Sander, F. (1976). Quantitative and qualitative aspects of the zooplankton and breeding patterns of copepods at two Caribbean coral reef stations. Estuarine and Coastal Marine Science, 4, 589-607.

Moore, E. A., \& Sander, F. (1979). A comparative study of zooplankton from oceanic, shelf, and harbor waters of Jamaica. Biotropica, 11, 196-206.

Morales-Ramírez, A. (2008). Caracterización cualitativa del zooplankton del Área de Conservación Marina Isla del Coco (ACMIC), Océano Pacífico de Costa Rica. Revista de Biología Tropical, 56 (Suppl. 2), 159-169.

Morales-Ramírez, A., \& Murillo, M. M. (1996). Distribution, abundance and composition of coral reef zooplankton, Cahuita National Park, Limón, Costa Rica. Revista de Biología Tropical, 44, 619-630.

Morales-Ramírez, A., Suárez-Morales, E., Corrales-Ugalde, M., \& Esquivel-Garrote, O. (2014). Diversity of free-living marine and freshwater Copepoda (Crustacea) in Costa Rica: a review. ZooKeys, 457, 15-33.

Mumby, P. J., Broad, K., Brumbaugh, D. R., Dahlgren, C. P., Harborne, A. R., Hastings, A., ... Sanchirico, J. N. (2008). Coral reef habitats as surrogates of species, ecological functions, and ecosystem services. Current Biology, 22, 941-951.

Núñez, J., Riera, R., \& Brito, M. (2010). Nuevos registros de poliquetos macrofaunales en las islas Salvajes. Vieraea, 38, 55-62.

Pennington, J. T., \& Stricker, S. A. (2002). Phylum Brachiopoda. In C. M. Young, M. A. Sewell \& M. A. Rice (Eds.). Atlas of Marine Invertebrate Larvae (pp. 441-461). London: Academic Press.

Perkins, T. H. (1998). Checklist of shallow-water marine polychaetous Annelida of Florida. In D. K. Gamp, W. G. Lyons \& T. H. Perkins (Eds.). Checklists of Selected Shallow-Water Marine Invertebrates of Florida (pp. 79-122). Florida, USA: Florida Marine Research Institute.
Plaisance, L., Caley, M. J., Brainard, R. E., \& Knowlton, N. (2011). The diversity of coral reefs: what are we missing? PLos ONE, 6, e25026.

Plate, S., \& Husemann, E. (1994). Identification guide to the planktonic polychaete larvae around the island of Helgoland (German Bight). Helgoland Marine Research, 48, 1-58.

Poss, S. G., \& Boschung, H. T. (1996). Lancelets (Cephalochordata: Branchiostomatidae): how many species are valid? Israel Journal of Zoology, 42, S13-S66.

Przeslawski, R., Ahyong, S., Byrne, M., Woerheide, G., \& Hutchings, P. A. T. (2008). Beyond corals and fish: the effects of climate change on noncoral benthic invertebrates of tropical reefs. Global Change Biology, 14, 2773-2795.

Rouse, G. W., \& Pleijel, F. (2001). Polychaetes. New York: Oxford University Press.

Ruíz-Ramírez, J. D., \& Salazar-Vallejo, S. I. (2001). Exogoninae (Polychaeta: Syllidae) del Caribe mexicano con una clave para las especies del Gran Caribe. Revista de Biología Tropical, 48, 117-140.

Salas, E., Molina-Ureña, H., Walter, R. P., \& Health, D. D. (2010). Local and regional genetic connectivity in a Caribbean coral reef fish. Marine Biology, $157,437-445$.

Salazar-Vallejo, S. I. (1996). Lista de especies y bibliografía de poliquetos (Polychaeta) del Gran Caribe. Anales del Instituto de Biología Serie Zoología, $67,11-50$.

Salazar-Vallejo, S. I., \& Díaz-Díaz, O. (2009). Maldanidae Malmgren, 1867. In J. A. de León-González, J. R. Bastida-Zavala, L. F. Carrera-Parra, M. E. García-Garza, A. Peña-Rivera, S. I. Salazar-Vallejo \& V. Solís-Weiss (Eds.). Poliquetos (Annelida: Polychaeta) de México y América Tropical (pp. 291309). Monterrey, México: Universidad Autónoma de Nuevo Léon.

San Martín, G. (1991). Grubeosyllis and Exogone (Exogoninae, Syllidae, Polychaeta) from Cuba, the Gulf of Mexico, Florida and Puerto Rico, with a revision of Exogone. Bulletin of Marine Science, 49, 715-740.

San Martín, G., \& Bone, D. (2001). Syllidae (Polychaeta) de praderas de Thalassia testudinum en el Parque Nacional Mocorroy (Venezuela). Revista de Biología Tropical, 49, 609-620.

Solís-Weiss, V. (1996). Atlas de Anélidos Poliquetos de la Plataforma Continental del Golfo de California (Informe final SNIB-CONABIO proyecto No. B113). Distrito Federal: México: Instituto de Ciencias del Mar y Limnología, Universidad Nacional Autónoma de México. 
Solís-Weiss, V., Londoño-Mesa, M. H., \& HernándezAlcántara, P. (2009). Trichobranchidae Malmgren, 1866. In J. A. de León-González, J. R. BastidaZavala, L. F. Carrera-Parra, M. E. García-Garza, A. Peña-Rivera, S.I. Salazar-Vallejo \& V. Solís-Weiss (Eds.). Poliquetos (Annelida: Polychaeta) de México y América Tropical (pp. 665-670). Monterrey, México: Universidad Autónoma de Nuevo Léon.

Støp-Bowitz, C. (1996). V. Polychaeta. In R. Gasca \& E. Suárez (Eds.). Introducción al Estudio del Zooplancton Marino (pp. 149-189). México: El Colegio de la Frontera Sur (ECOSUR/CONACYT).

Suárez-Morales, E., \& Rivera, E. (1998). Zooplancton e hidrodinámica en zonas litorales y arrecifales de Quintanra Roo, México. Hidrobiológica, 8, 19-32.

Suárez-Morales, E., Carrillo-Baltodano, A., \& MoralesRamírez, A. (2013). Report on some monstrilloids (Crustacea: Copepoda) from a reef area off the Caribbean coast of Costa Rica, Central America with description of two new species. Journal of Natural History, 47, 619-638.

Temkim, M. H., \& Zimmer, R. L. (2002). Phylum Bryozoa In C. M. Young, M. A. Sewell \& M. A. Rice (Eds.). Atlas of Marine Invertebrate Larvae (pp. 411-427). London: Academic Press.

Tovar-Hernández, M. A., \& Salazar-Vallejo, S. I. (2006). Sabellids (Polychaeta: Sabellidae) from the Grand Caribbean. Zoological Studies, 45, 24-66.
Warner, G. F., \& Goodbody, I. (2005). Jamaica. In P. Miloslavich \& E. Klein (Eds.). Caribbean Marine Biodiversity: The Known and the Unknown (pp. 57-70). Pennsylvania, USA: DEStech Publications.

Webber, M. K., Roff, J. C., Chisholm, L. A., \& Clarke, C. (1996). Zooplankton distributions and community structure in an area of the South coast shelf of Jamaica. Bulletin of Marine Science, 59, 259-270.

Wehrtmann, I. S., Cortés, J., \& Echeverría-Sáenz, S. (2009). Marine biodiversity of Costa Rica: Perspectives and conclusions. In I. S. Wehrtmann \& J. Cortés (Eds.). Marine Biodiversity of Costa Rica, Central America (pp. 521-533). Berlin, Germany: Springer + Business. Media B.V.

Wilson, W. H. (1991). Sexual reproductive modes in polychaetes: classification and diversity. Bulletin of Marine Science, 48, 500-516.

Yáñez-Rivera, B. (2009). Amphinomidae Savigny in Lamarck, 1818. In J. A. de León-González, J. R. Bastida-Zavala, L. F. Carrera-Parra, M. E. GarcíaGarza, A. Peña-Rivera, S. I. Salazar-Vallejo \& V. Solís-Weiss (Eds.). Poliquetos (Annelida: Polychaeta) de México y América Tropical (pp. 77-87). Monterrey, México: Universidad Autónoma de Nuevo Léon, México.

Young, D. K., \& Young, M. W. (1982). Macrobenthic invertebrates in bare sand and seagrass (Thalassia testudinum) at Carrie Bow Cay, Belize. Smithsonian Contributions to the Marine Sciences, 12, 115-126. 